\title{
Comparison of the liquid limit of loess defined by the Vasiliev and Casagrande test methods
}

\section{Сравнение на границата на протичане на льос, определена по методите на Василев и Казагранде}

\section{Boriana Tchakalova \\ Боряна Чакалова}

Geological Institute, Bulgarian Academy of Sciences, Acad. G. Bonchev str., bl. 24, 1113 Sofia, Bulgaria;

E-mail: boriana@geology.bas.bg

\begin{abstract}
The paper compares liquid limit values obtained by the Vasiliev and Casagrande apparatus in line with BDS 648:1984 and BDS EN ISO/ TS 17892-12:2018, on the basis of testing 25 silty loess samples. The results indicated that compared with the Vasiliev apparatus, the Casagrande apparatus gives a higher liquid limit. An equation allowing conversion of the liquid limit obtained by the Vasiliev cone penetrometer to the liquid limit by the Casagrande apparatus has been developed.
\end{abstract}

Keywords: liquid limit, loess soil, Casagrande apparatus, Vasiliev apparatus.

\section{Introduction}

The liquid limit is one of the most commonly used classification parameters of soils. A number of geotechnical properties of soils, like deformability, shear strength, swelling potential, permeability, liquefaction, cation exchange capacity, specific surface, etc., are correlated with the liquid limit (e.g Santamarina et al., 2002; Sharma, Bora, 2003; Yilmaz, 2004; Spagnoli, Shimobe, 2020).

The liquid limit of soils was first suggested by Atterberg (1911) and later standardized by Terzaghi (1926) and Casagrande (1958) for implementation in geotechnical and civil engineering research and practice. The method of liquid limit determination, using the Casagrande apparatus, has been adopted in geotechnical standards in the United States of America (ASTM, AASHTO), the United Kingdom (BSI), European Union (EN), Japan (JIS) and many other countries.

In Bulgaria, the geotechnical design according to the European norms (EN) has been in force since 2010. Until then the liquid limit in Bulgaria as well as most of the Eastern European countries was identified by Vasiliev's cone penetrometer
(Vasiliev, 1942, 1949; GOST 5184:49; BDS 649:1971). The liquid limit obtained by Vasilev's test $\left(w_{L}{ }^{v}\right)$ differs from the liquid limit determined by Casagrande cup $\left(w_{L}^{c}\right)$ apparatus.

Loess soil forms an almost continuous cover in North Bulgaria and amounts to approximately $13 \%$ of the territory of the country. Because of its specific engineering properties, many geotechnical classification tests were performed and plenty of archive test results are available. There is a necessity for these results to be used in new studies and projects. For that reason, a correlation between the liquid limit values determined by both methods would have a valuable application. The paper aims to present a comparison of results for liquid limit values of loess soil determined by the Vasiliev cone and Casagrande cup apparatuses.

\section{Materials and methods}

In the study, 25 loess soil samples from Kozloduy town area (North Bulgaria) were analyzed. The samples were taken from typical silty loess at depths between 1.5 and $9.0 \mathrm{~m}$ below the ground level. The samples average particle size distribution is as fol- 
lows: gravel $>2 \mathrm{~mm}-0 \%$; sand $2-0.063 \mathrm{~mm}-4 \%$; silt $0.063-0.002 \mathrm{~mm}-96 \%$ and clay $<0.002 \mathrm{~mm}$ $-0 \%$. All samples are classified according to BDS EN ISO 14688 - 2:2018 as CIL (low plasticity clay) and according to USCS (ASTM D 2487-17e1) as CL (lean clay).

The liquid limit was obtained according to BDS 649:1971 and BDS EN ISO/ TS 17892-12:2018. For the determination of $w_{L}{ }^{v}$ a standard Vasiliev cone penetrometer with an apex angle of $30^{\circ}$, mass of $76 \mathrm{~g}$, and penetration value of $10 \mathrm{~mm}$ was used in line with BDS 648:1984. As recommended in 5.4 of BDS EN ISO/ TS 17892-12:2018, the Casagrande apparatus with a hard base percussion cup and 25 blows was used to obtain the $w_{L}^{c}$ values.

The tests were conducted on air-dry loess soil samples passing $425 \mu \mathrm{m}$. The samples were mixed thoroughly with a small amount of distilled water to adjust the water content of the remoulade soil paste to the desired consistency and they were left in an airtight container for approximately $4 \mathrm{~h}$. The samples were then tested on both devices to obtain first data points. To obtain second points, soil specimens were remixed adding distilled water to increase the water content. Drying of the specimens between tests was prevented by putting them in an airtight container. This process was continued to obtain at least four water contents values for each sample and method. The results were plotted on semilogarithmic graphs: cone penetration depth against water content and number of blows against water content. The water contents matching to a cone penetration of $10 \mathrm{~mm}$ from the first graph were defined as $w_{L}{ }^{\nu}$. From the Casagrande cup graph the
Table 1. Statistical analysis of the liquid limit test results

\begin{tabular}{lcc}
\hline Parameter & $\mathrm{W}_{\mathrm{L}}{ }^{\mathrm{v}}$ & $\mathrm{W}_{\mathrm{L}}{ }^{\mathrm{c}}$ \\
\hline Mean & 27.5 & 33.3 \\
Standard error & 0.30 & 0.43 \\
Median & 27.3 & 32.6 \\
Mode & 26.7 & 32.1 \\
Standard deviation & 1.49 & 2.13 \\
Range & 6.5 & 8.7 \\
Minimum & 25.1 & 30.2 \\
Maximum & 31.6 & 38.9 \\
Count & 25 & 25 \\
\hline
\end{tabular}

water contents corresponding soil to 25 numbers of blows were defined as $w_{L}^{c}$.

Least square linear regression was used to establish empirical models between $w_{L}^{v}$ and $w_{L}^{c}$. The $w_{L}{ }^{v}$ was used as a predictor variable to explain the response variable $w_{L}^{c}$. A graph of $w_{L}{ }^{v}$ was plotted against $w_{L}^{c}$ and the coefficient of determination $\mathrm{R}^{2}$ was used to determine the quality of the relationship; the higher the value of $\mathrm{R}^{2}$, the stronger relationship between the variables. A strong relationship between the predictor variable and the response variable leads to a reliable empirical equation.

\section{Results and discussion}

Comparison of the liquid limits of the loess soil, determined by the Vasiliev cone penetrometer $w_{L}{ }^{v}$ and Casagrande method $w_{L}{ }^{c}$ is presented in Table 1 and Fig. 1a. It was observed that the liquid limits
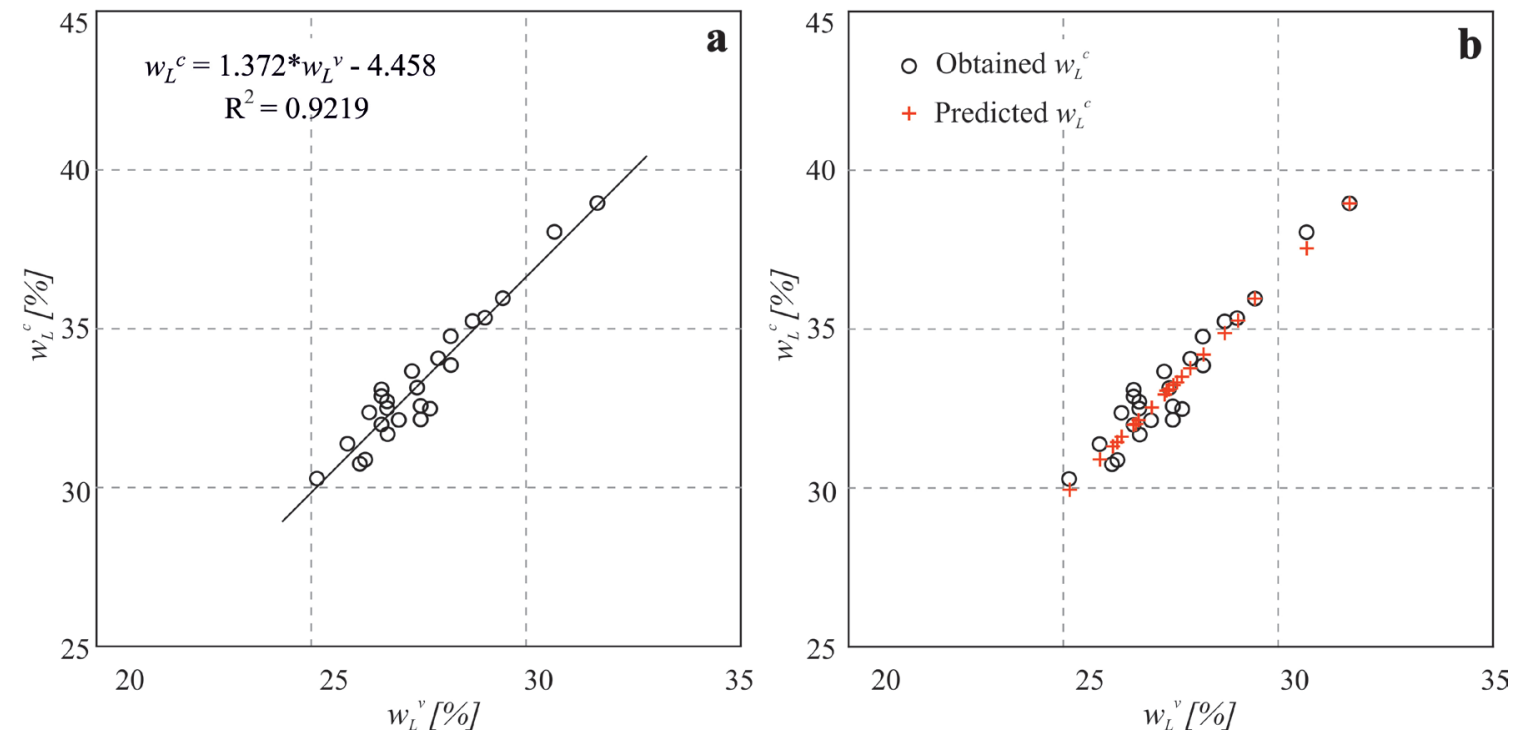

Fig. 1. $a$, Vasiliev cone penetrometer $\left(w_{L}^{v}\right)$ vs Casagrande apparatus $\left(w_{L}^{c}\right)$ liquid limit with the regression line; $b$, comparison of the calculated $w_{L}^{c}$ values obtained by the correlation [1] and the Stefanoff's (1957) equation 
determined by the Vasiliev cone penetrometer were rather lower than those obtained by the Casagrande apparatus. This is consistent with the results of other studies (e.g. Stefanoff, 1957; Škopek, Ter-Stepanian, 1975; Gruchot et al., 2017).

The coefficient of determination is $\mathrm{R}^{2}=0.92$ (Fig. 1a), which means that there is high correlation between liquid limits obtained by both methods. The following equation was derived from least square linear regression analysis:

$$
w_{L}^{c}=1.37 * w_{L}^{v}-4.46
$$

where, $w_{L}{ }^{c}$ is the Casagrande apparatus liquid limit, and $w_{L}{ }^{v}$ is the Vasiliev cone penetrometer liquid limit. The derived empirical equation is applicable for low plasticity silty soils. The high value of the coefficient of determination demonstrates the validity the proposed relationship. The calculated $w_{L}{ }^{c}$ values differ up to $\pm 1 \%$ from the $w_{L}^{c}$ values obtained by tests. The limitation of this empirical equation is that it is only applicable for silty loess soil with values of $w_{L}{ }^{v}$ in the range $25-35 \%$.

A comparison of the calculated $w_{L}^{c}$ values obtained by the current empirical correlation [1] and Stefanoff's (1957) one is shown on the Fig.1b. The results of $w_{L}{ }^{c}$ from both correlations are very similarthe difference is less than $1 \%$. However it has to bear in mind that the Stefanoff's correlation is not derived especially for silty loess soils.

\section{Conclusions}

In order to compare liquid limit values of silty loess soil determined by the Casagrande cup and the Vasiliev apparatus, 25 silty loess samples were tested. Based on the statistical analysis of test results the following conclusions can be drawn:

- The liquid limits determined by the Vasiliev cone penetrometer were rather lower than those obtained by the Casagrande apparatus;

- There is a strong correlation between liquid limits obtained by both methods;

- An equation, allowing conversion of the liquid limit obtained by the Vasiliev cone penetrometer to the liquid limit by the Casagrande apparatus has been derived.

\section{References}

ASTM D 2487-17e1. Standard Practice for Classification of Soils for Engineering Purposes (Unified Soil Classification System).

Atterberg, A. 1911. Die Plastizität der Tone. - Internationale Mitteilungen der Bodenkunde, 1, 4-37.

Casagrande, A. 1958. Notes on the design of the liquid limit device. - Géotechnique, 8, 2, 84-91; https://doi.org/10.1680/ geot.1958.8.2.84.

BDS 649:1971. Soils. Method for Laboratory Determination of the Liquid Limit (in Bulgarian).

BDS EN ISO 14688 - 2:2018. Geotechnical Investigation and Testing - Identification and Classification of Soil - Part 2: Principles for a Classification (ISO 14688-2:2017).

BDS EN ISO/ TS 17892-12:2018. Geotechnical Investigation and Testing - Laboratory Testing of Soil. Part 12: Determination of Liquid and Plastic Limits.

GOST 5184-49. Soils. Method of Laboratory Determination of border of the flowability (in Russian).

Gruchot, A., E. Zawisza, T. Zydroń, E. Klimek. 2017. The impact of a test method on the liquid limit of the selected cohesive soils. - Communication Review, 72, 5, 15-20 (in Polish).

Sharma, B, P. Bora. 2003. Plastic limit, liquid limit and undrained shear strength of soil-reappraisal. - J. Geotech. Geoenv. Eng., 129, 8, 774-777; https://doi.org/10.1061/ (ASCE)1090-0241(2003)129:8(774).

Santamarina, J., K. Klein, Y. Wang, E. Prencke. 2002. Specific surface: determination and relevance. - Can. Geotech. J., 39, 233-241; https://doi.org/10.1139/t01-077.

Škopek, J., G. Ter-Stepanian. 1975. Comparison of liquid limit values determined according to Casagrande and Vasilev. - Géotechnique, 25, 1, 135-136; https://doi.org/10.1680/ geot.1975.25.1.135.

Spagnoli, G., S. Shimobe. 2020. Statistical analysis of some correlations between compression index and Atterberg limits. - Environ. Earth Sci., 79, 532; https://doi.org/10.1007/ s12665-020-09272-0.

Stefanoff, G. 1957. Consistency of engineering soils. - In: Trudove na Nauchnoizsledovatelskia Stroitelen Institut - NISI, Sofia, 159-197 (in Bulgarian).

Terzaghi, K. 1926. Simplified soil tests for subgrades and their physical significance. - Publ. Roads, 7, 8, 153-170.

Vasiliev A.M. 1942. A simplified method for determining the liquid limit of clay soils. - Stroitelstvo dorog. No. 1 (in Russian).

Vasiliev, A. 1949. Osnovy Sovremennoj Methodiki i Tehniki Labornyh Opredelenij Fizicheskih Svoistv Gruntov. Moscow, Mashstroyizdat, 158 p. (in Russian).

Yilmaz, I. 2004. Relationships between liquid limit, cation exchange capacity, and swelling potentials of clayey soils. Eurasian Soil Sci., 37, 5, 506-512. 